\title{
Perception of Auditors and Auditee on Public Sector Performance Audits
}

\author{
Widhi Setyo Pratama*
}

\begin{abstract}
This study aims to discuss the perceptions of auditors and auditees on public sector performance audits. This study analyzes how social processes and interactions are both in the performance audit process. They are in case of changes in the auditor's role in the future, which have the potential to cause problems of independence. The other is that the benefits and impacts of performance audit results have not been felt significantly. By using a qualitative approach, this study analyzes how the perceptions and relations of the two actors in the performance audit. In-depth and structured interview techniques are used as data collection methods from participants from auditors and auditees. Auditee's response was also analyzed to determine the extent of their resistance to the actions of auditors and their perception of the benefits of performance audits. The results of the study show that performance audits have not given a significant impact on policy performance improvements. There are differences in perceptions about expectations for the role of the auditor and the provision of recommendations that are more solutive. A significant difference in perception is also shown in the auditor's understanding of the auditee's business processes. It is due to the issues in the auditor's qualifications and experience that are influenced by their educational background. Other findings are the potential disruption of auditor independence due to lack of operationalization of the concept of independence and the amount of pressure from the auditee.
\end{abstract}

\section{Keywords:}

performance audit; perception; auditor; auditee; role taking concept

\section{Introduction}

This study aims to analyze the perceptions of auditors and auditees on public sector performance audits in Indonesia. This research is important because there are several important issues that occur within the scope of the institution, public debate, and the benefits of the performance audit itself. Performance Audit in Indonesia itself is carried out by The Audit Board of The Republic of Indonesia (BPK RI) for public sector programs, policies and entities.

In the existing studies and literature, several important issues can be noted through various discussions and perspectives on the dynamics of performance audits conducted by the Supreme Audit Institution (SAI). First, there are changes in the role of auditors in the future that have the potential to cause problems of independence disorders (Gendron, Cooper, \& Townley, 2001; Pollitt \& Summa, 1997; Sikka \& Willmott, 1995). Second, the benefits and impact of performance audit results have not yet been felt in real terms (Morin, 2014; Raudla, Taro, Agu, \& Douglas, 2016; ReichbornKjennerud, 2015). Third, there is still a mindset of compliance audits in performance audits (Lapsley \& Pong, 2000; Leeuw, 1996; Stewart

\footnotetext{
- Auditor at Audit Board of The Republic of Indonesia Email: widhisetyopratama@gmail.com
} 
\& Walsh, 1994). And fourth, there are differing views between auditors and auditors regarding audit results (Lindeberg, 2007; Vikkelsø, 2007).

However, the research mentioned earlier has several limitations. It includes the lack of studies on performance audits in the public sector compared to studies in the private sector. This might lead to different conclusions due to the different objectives of the two entities. Furthermore, studies on perceptions of the auditee or audited parties are still lacking and can be explored further. The Auditee is an entity that is directly involved with the auditor in the performance audit process. Good relations and communication from both of them are certainly important keys for improving public programs or organizations. Another limitation is that most studies are quantitative methodbased research, namely using surveys or questionnaires. Consequently, this has the potential to hinder a new understanding of the processes that occur in a performance audit. The method is less helpful in explaining how auditors and clients understand their role, why there are differences in perception, and how it affects the performance of the organization being audited.

Based on the research background above, the formulation of the main problem in this study is "How are the perceptions of auditors and auditees in viewing the benefits of performance audits as an effort to improve the performance of public sector organizations in Indonesia". Furthermore, the formulation of the problem is outlined in three questions: First, how do auditors and auditees perceive the concept of performance audit? Are there differences in perceptions that have the potential to cause conflict between the two? Second, how do auditors and auditees assess the impact of performance audits on public organizations in Indonesia? To what extent does the performance audit affect organizational change? Third, how do auditors and auditees perceive the impact of performance audits, related to their interactions at the personal, interpersonal, and external levels? Do these interactions support or hinder the more effective performance?

\section{Theoretical Background}

Performance audit is defined as independent evaluations in economic aspects, efficiency and effectiveness of government programs, policies, functions, and organizations related to their compliance with laws and regulations (Davis, 1990; Parker, 1986). Performance audit is a form of audit to establish conclusions based on evaluation of adequate and reliable evidence of a criterion. In this case, performance audits provide objective analysis to help management and those responsible for governance and supervision in using information to improve the performance and operation of certain programs.

To analyze how auditors and auditees see performance audits, the concept role taking (Katz \& Kahn, 1978) was used. It is used to see whether there are differences in perceptions and expectations between the two related to the benefits of performance audits in improving the performance of public policies or organizations. In this concept, role taking occurs when members of an organization learn and accept roles that originate from organizational rules, instructions and from feedback. This concept involves individuals with assumed roles who are expected to align their actions with social norms, so that each individual sees themselves as the object of desired social transactions (Heimer \& Matsueda, 1994).

In addition, this study uses the concept of audit expectation gap to see the extent of differences in perspectives that arise in the performance audit process. According to Humphrey, Moizer, and Turley (1993), the gap in audit expectations comes from different expectations. It is regarding the function of independence and professionalism between auditors and the public, including users of other 
financial statements. The audit expectation gap is consistently focused on a number of key issues, namely: the role and responsibilities of the auditor, the nature and meaning of the message of the audit report, the quality of the audit function, and the structure and arrangement of the profession. Humphrey et al. (1993) exemplify differences in perceptions of roles between auditors and auditees, namely about what auditors can expect fairly and what the auditor believes must be expected of them.

To analyze the perceptions of the auditee, this study uses a typology of strategic responses to organizational change from Oliver (1991). In this typology, five types of strategies and tactics can be used by organizations or auditees in responding to auditor influences and performance audits. The five types of strategic response typologies in the change process are agreeing, compromising, avoiding, challenging, and manipulating.

\section{Methods}

This study uses a qualitative approach to explore the perceptions of auditors and auditors on public sector performance audits in Indonesia. This qualitative research is expected to be able to provide an overview of various phenomena, explain relationships, review hypotheses, get meaning and implications of a problem (Alasuutari, 2010). An ethnographic approach was used to analyze how the interaction and communication between auditors and auditees, and how they feel the role in the performance audit.

Sources of data were taken from three performance audit reports carried out on three different entities. They are: the Performance Audit Report on the National Health Insurance Program in 2015 and the first semester of 2016, Performance Audit Report on the Poverty Reduction Program in the Provincial Government of Anom 2010 to 2014, and Performance Audit Report on the Implementation of Accrual-Based SAP in the
Alit City Government in 2014 Fiscal Year to 2015. The number of participants was 25 people who came from auditors and auditees.

Primary data collection used interview techniques, especially semi-structured interviews. Interview techniques are very suitable for examining topics where various levels of meaning need to be explored. It was used to see individuals or groups of people from within, and to understand how and why they arrive at their particular perspective (Cassel \& Symon, 1994).

\section{Results and Discussion \\ Perceptions and Expectations of Auditors and Auditees on the Purpose and Benefits of Performance Audit}

The results of the study indicate that there are gaps in expectations and perceptions between auditors and auditees regarding performance audit practices. The auditor does provide conclusions and recommendations, which are expected to bring changes to the policy. However, the auditee considers that the impact of changes or improvements in performance has not been felt in real terms. In addition, the auditee also felt that performance audits were only routine processes in the context of independent third party evaluations. In addition, it is as a form of their accountability to the community.

This perception difference is due to the auditor's assessment of the 3E aspect that is felt to be insufficient and cannot provide relevant and operational recommendations. In this study, it can be concluded about the auditor's professional capacity and expertise in carrying out the roles mentioned above. The first conclusion, the auditor does not need a special educational background or special qualifications in carrying out a performance audit. The State Financial Examination Standard states that the auditor must collectively have the knowledge, experience, and competencies needed in carrying out the audit. These competencies 
include knowledge and experience of audits conducted, understanding of standards and provisions of legislation, understanding of the entity's operations, as well as the ability and experience to practice professional judgment. Auditors' competencies are especially needed to detect fraud and misrepresentation of financial statements. In the context of performance audits, auditors must have competencies that are more than just financial audits. In this regard, the scope of performance audits is very broad and concerns issues that are developing in society (Reichborn- Kjennerud \& Johnsen, 2015). Because of that, auditors are required to have more capability, especially to assess or measure performance outside the financial sphere, which certainly provides more challenges because it involves a higher level of subjectivity and professional judgment. However, there is no single provision that specifically requires that auditors must pass certain tests or competency to carry out performance audits. This is different from financial audits which require auditors to understand how the accounting system works. It would be better if they have professional certification in this matter. The data obtained shows that the auditor performs a much broader role when conducting a performance audit. They must focus on far more complex and broader issues, which require the use of subjectivity. The wide scope and lack of professional qualifications make the auditor's task more difficult and potentially lead to conflict with the auditee.

Second, auditors still play the same role when conducting performance audits and financial audits or compliance. When conducting a performance audit, the auditor's mindset is still the same as when they conduct a financial audit or compliance. It is how to find findings by comparing procedures that must be done with their implementation in the field. The similarity of mindset makes auditors unable to play a broader role in providing new insights or knowledge to improve policy performance. Related to this, the auditor must be able to show the auditee that the performance audit is not just a financial audit or compliance. Auditors must be able to establish communication with the auditee effectively, so it can change the auditee's view of performance audits.

The active participation of auditors in improving performance is also a problem. Auditors are not only asked to provide general recommendations, but they can also provide more technical recommendations. The Auditee hopes that the auditor will look deeper into the problems and impacts of the policy, so that the recommendations given are more applicable and reasonable. In addition, the auditee is more pleased if auditors can actively assist them in monitoring policy developments. This existence contributes to the role of the auditor, from being a supervisor to becoming a consultant, changes that are considered unreasonable for some auditors. The auditor believes that recommendations must be given only to the extent that they are responsible for the performance audit, and the auditee is still responsible for improving or improving its performance. Changes in this role have the potential to disrupt auditor independence and they are aware of this. For this reason, special formulations and guidance are needed on how the concept of independence is real, so that audit results are also more reliable in the eye of public.

\section{Social Process in the Concept of Role Taking}

This study also shows that there are several types of conflicts that occur related to performance audits. These conflicts include personal role conflict, excessive role and conflict between roles. Personal role conflicts involve changing proactive roles that result in impaired independence values. The emergence of excessive roles is related to the demand to play a direct role in policymaking and pressure to provide more operational recommendations. 
In conflict between roles on the other hand, related to the response and resistance of the auditee. This study also revealed social processes and responses between auditors and auditees in their relationships. These social factors include personal, interpersonal, and external factors.

In personal factors, educational background and competence are one of the factors that play a role in supporting the relationship between auditors and auditees. With the development of current performance audit practices, it is inevitable that auditors must continue to develop their competencies in a sustainable manner and pay attention to issues that develop in the community. However, the auditor's competence to assess aspects of $3 \mathrm{E}$ in accordance with the objectives in the performance audit is deemed insufficient and problematic, although there is already a corridor to develop competencies, as stipulated in audit standards. However, this will not guarantee and will not be sufficient to ensure that the auditor has sufficient competence in achieving the objectives of the performance audit. This is because drawing conclusions and determining recommendations in performance audit practices involve many subjective judgments from auditors that are referred to as professional judgment. In this case, the auditor must be trained to use their insights and intuition to be involved in every process in the performance audit. Unlike financial audits or compliance audits, every aspect of the performance audit starts from determining the audit topic, determining audit objectives, planning audit programs, obtaining and analyzing evidence, and determining criteria something unique. This shows that performance audits really need the ability and judgment of an auditor, so that the audit results will have a real impact.

There is no specific requirement regarding educational background or qualifications in a performance audit. As a result, the emergence of role conflict is caused by a lack of understanding of the auditee's business processes. Within the scope of the auditee, most auditor work in an environment that requires high and specific professional qualifications. This condition causes a high resistance to the auditor's recommendations. It causes auditor experiences difficulties when he is in the environment and profession that he does not understand. In addition, the extents to which the aspects covered and the uncertainty of the methods used in the performance audit have contributed to the conflict between the auditor and the auditee. Unlike financial audits, the methods and procedures used in performance audits do not depend on one or two methods, but are very broad. In a performance audit, there are no consistent procedures that can be applied to the auditee with different business processes. The auditor must try various methods and techniques to analyze the problems that arise in implementing government policies. Auditors have the weakness to choose the right procedures and methods, and there is a tendency to use the same methods as in financial audits or compliance.

Auditors who have inadequate competencies are more at risk of failing to present useful audit results. This has resulted in a negative impact on the auditee they examined. The findings of Brazel and Agoglia (2007) state that auditors who have a specialization in a particular field, will be able to plan audits better on more complex systems, than those who do not. This specialization is usually done through examination and certification. For example, expertise in the field of information systems, expertise in the field of fraud, expertise in the field of internal audit, expertise in the field of risk management, and so on. Those who do not have certain specialties will undergo the possibility of failing more in assessing risk and determining the purpose of the audit in the system. This is also in accordance with the finding of Van Peursem (2004) who expressed 
the lack of professional abilities of auditors and the possible negative impacts caused by the audited entity. In this case, performance audits involving auditors who have limited qualifications and experience are likely to cause conflict. Moreover, it influences the auditor's ability to convince the auditee in improving the performance of their policies or organizations. The Auditee can assume that non-significant findings and exposures disclosed in a performance audit can actually risk the auditor's reputation in the audit department. This resulted on the auditee having little confidence in the results of the audit performance. They may be reluctant to follow up their recommendations, or even lose interest in the entire audit process.

On interpersonal level, the dilemma of independence and the search for the concept of ideal freedom is one of the emerging perspectives. Issues related to independence arise with pressure on auditors and changes in their roles from a supervisor to a more active role. There are strong contradictions, which cause role conflicts between auditors and auditees. The Auditee considers that it is better for auditors to play an active role in helping them improving performance. On the other hand, auditors reply that their duties and responsibilities are clear, and the authority to improve performance is entirely the responsibility of the auditee. The existence of a perception gap between the auditor and the auditee regarding the supposed role of an auditor is an important factor regarding the attitude of auditor independence. Auditors are required to be free from all interests, but in the field, they are required to establish good relations with the auditee to obtain sufficient evidence. In another perspective, auditors build communication informally, as a solution to improving organizational performance. In addition, the dynamics of the audit process in the field contributes to the use of authority that affects objectivity.
Interpersonal factors are then related to dilemmas in determining audit objectives and criteria. In performance audits, auditors involve the auditee in the entire audit process, starting from planning, implementation, to reporting. This is different from financial audits and compliance audits, where the involvement of the auditee usually starts during the implementation and reporting stages. This difference is closely related to the purpose of the performance audit, namely to assess the economic aspects, efficiency and effectiveness of a policy. It also provides improvements and improves performance on it. In this case, the auditee is considered to best understand the business process of the policy they are running. In a result, the auditor invites the auditee to provide views on aspects that should be assessed in the policy. Professional auditors must be careful so that in determining the audit objectives they are not trapped in a vortex of political controversy that tends to weaken their credibility. The policy process is a political process, so auditors must be careful in setting audit objectives. In addition, the determination of the audit objectives must also be supported by determining the appropriate audit criteria so that the performance improvement objectives will be achieved.

The dilemma in determining the objectives of a performance audit also influences the determination of audit criteria. Audit criteria are the benchmarks used in examining and assessing the principal. The benchmark in this case includes information disclosed in the management and accountability of state finances, including benchmarks for relevant presentation and disclosures. Criteria are the core of the entire audit process and without clear criteria, it impossible for the auditor to assess the performance of a policy (Pollitt et al., 1999). In a performance audit, there must be an audit criteria agreement between the auditor and the auditee. The aim is to unite perceptions so that each party can understand the criteria 
to be used. Reichborn-Kjennerud (2011) argues, when auditees agree with audit criteria, this will convince them that performance audits provide added value for performance improvement. Each type of audit uses criteria that are in accordance with the context of the audit. The criteria used in performance audits differ from the criteria in financial audits and compliance audits. In financial audits or compliance, the criteria used are standardized standards and guidelines. It can be said, in the audit, the criteria used between one audit with another audit remain or almost the same. This is different from the criteria used in a performance audit. The auditor must develop his own audit criteria because of the unique characteristics of each object of examination. The audit standard states, an auditor must have the competence to determine performance audit criteria through various sources and determine criteria that are precisely in accordance with the objectives of the audited object. The problem is that the audit criteria in performance audits cover a broad aspect, when compared to audit criteria in the audit finance. The auditor must be able to explain how the best practice concept is. Their job together with the auditee is to develop criteria so that innovation in public services can be fulfilled.

Another challenge related to the determination of performance audit objectives is the existence of moral issues in conducting performance assessments. Kerssens-van Drongelen and Fisscher (2003) argue that the process of measuring performance by involving authority and responsibility in the organization as a whole is a dynamic process. It is impossible to blame individuals without involving other individuals. In theory, in an organization each employee is expected to accept all the authority and means needed to carry out and take responsibility for the task. However, in practice it is often found that staff responsibilities are often delegated, while authority in the task is not given. As a result, there are situations where an employee or department has little authority, but the responsibility is large, and vice versa. Problems arise when the working mechanism does not work. This effects on blaming someone, while those who delegate responsibility feel they have no moral demands. In fact, factors in forming responsibility and authority are not static, but are dynamically dependent on the situation and capabilities possessed.

External factors are related to value added ambiguity in the performance audit. Ambiguity in performance audits is an inherent factor. The results of the study show that the emergence of a level of ambiguity surrounding the performance audit process stems from the many potential interpretations of this audit idea. This is possible because there is no educational institution or professional institution as a place to develop and improve the scientific field of performance audits. Because of these limitations, everyone has the right to interpret and develop their own understanding. It may be in the form of how the mechanical value added field will be presented in the performance audit process. The value added ambiguity is not only influenced by the factors determining audit criteria. There are other factors like the auditor's understanding, adequacy evidence, unclear recommendations, and lack of detail. Moreover, it is too focused on economic aspects and efficiency, and an increase in costs compared to the benefits provided in this audit. The existence of valueadded ambiguities in performance audits also occurs, when performance measurements are obtained through the results of quantification. This occurs when auditors have difficulty in understanding the qualitative characteristics of performance measurement, and they try to avoid this measurement. As a result, added value in measuring performance is not optimal even though performance audits are said to only be ritual verification (Power, 2000). This confusion of value added in 
performance audits extends to the problem of auditor independence. This relates to the extent and depth of the intensity of an auditor in providing added value, but does not affect his independence. It also talks about whether their involvement in providing informal advice can also interfere with independence. Unclear value added is closely related to the breadth of aspects and multi-purpose to establish policies. This makes the auditor experience difficulties when deciding which area will be the scope of the audit. In addition, policy impact factors that can only be seen in the long term create a perceived bias that policies have succeeded or not.

The problem in the ambiguity of value added performance audits can also occur when the policy set by the government is a policy with many objectives. It is very difficult to determine what and how the added value is expected from a performance audit. For example, in a performance audit on poverty reduction, there are many programs/activities carried out by the auditee while one program with another program does not have to be related. Many of these programs will cause dilemmas for auditors to decide which programs will be audited. They have to be more specific or rather choose to audit all programs so that more general conclusions will be obtained. Related to this, there will be potential conflicts of the auditee fund auditors that are sourced from the needs and intentions of each party. It also conflicts on how to sort out which objects are considered more important. The use of criteria that tend to be stagnant and lack innovation, results in less effective value added given in the performance audit. Auditors rarely use audit criteria outside of existing procedures or conditions. In addition, the auditee did not know that the criteria in the actual performance audit did not have to come from these provisions. This is one of the communication problems caused by asymmetrical information about performance audits.

\section{Reflections on the Auditor's and Auditee's Perception of Performance Audit}

This study uses three main concepts to analyze relations, social influences, and actions of auditors and auditees in performance audits. They are the concept of role taking by Katz and Kahn (1978), the concept of audit expectation gap and the concept of strategic response Oliver (1991). By using the concept of role taking, researcher can analyze how auditor behavior in developing their roles and expectations of the auditee. In addition, the analysis spread on the influences of the auditee in order to realize these expectations. However, the auditee does not always accept the efforts of auditors and they develop perceptions about what and how the auditor should be able to do. It can be analyzed by using the concept of gap expectation audit. Furthermore, by using the concept of strategic response researcher can discuss how the auditee's resistance to the behavior and actions of the auditor. By using these three concepts, important findings in this study are concluded as follows.

Based on the concept of role taking, there are several important concepts in performance audits. They are the role of auditors and performance audits according to official documents, perceptions of auditors, perceptions of auditees, and social processes that surround relations between auditors and auditees. In the relevant official document, it is stated that the purpose of the performance audit is to provide an assessment of the economic aspects, efficiency and effectiveness, or other aspects. Moreover, it provides improvements or improves the performance of a policy or organization. The document also mentions the role of the auditor, namely the authority to provide recommendations as long as they do not exceed their responsibilities. The responsibilities referred to include providing recommendations with the aim of encouraging or providing new insights for the auditee in 
Table 1.

Relationship between the Concept of Role Taking, Audit Expectation Gap, and Strategic Response

\begin{tabular}{|c|c|c|}
\hline \multicolumn{2}{|c|}{ Important Concepts } & Findings \\
\hline \multirow{13}{*}{$\begin{array}{l}\text { Role Taking } \\
\text { Concept }\end{array}$} & Auditor's Role & a. The purpose of the performance audit is to provide an assessment of aspects E 3 \\
\hline & $\begin{array}{l}\text { \& Performance } \\
\text { Audit in }\end{array}$ & $\begin{array}{l}\text { and other aspects, and provide recommendations for improvement / improvement } \\
\text { in performance }\end{array}$ \\
\hline & accordance & b. Auditors provide recommendations as long as they do not exceed their responsibilities. \\
\hline & $\begin{array}{l}\text { with Official } \\
\text { Documents }\end{array}$ & Recommendations are encouraging improvements to weaknesses found \\
\hline & Auditor & The auditor provides conclusions and recommendations with the aim of providing \\
\hline & Perception & awareness to the auditee, not to play a direct role in decision making \\
\hline & $\begin{array}{l}\text { Auditee } \\
\text { Perception }\end{array}$ & $\begin{array}{l}\text { Recommendations should be solutive and operational. In addition, auditors should play } \\
\text { a direct role in improving performance and supervising the performance of the auditee }\end{array}$ \\
\hline & Role Conflict & $\begin{array}{l}\text { a. Individual Role Conflict: the change in proactive roles results in impaired } \\
\text { independence values }\end{array}$ \\
\hline & & $\begin{array}{l}\text { b. Excessive Role: there is a demand to play a direct role in policy making and pressure } \\
\text { to provide more operational recommendations }\end{array}$ \\
\hline & & c. Inter-role conflict: conflict related to the response and resistance of the auditee \\
\hline & Social Process & $\begin{array}{l}\text { a. Personal level: educational background and determination of audit procedures / } \\
\text { methods }\end{array}$ \\
\hline & & $\begin{array}{l}\text { b. Interpersonal level: independence and search for ideal independence, the dilemma } \\
\text { of determining audit objectives and criteria }\end{array}$ \\
\hline & & c. External level: value added ambiguity in performance audits \\
\hline \multirow{5}{*}{$\begin{array}{l}\text { Audit } \\
\text { Expectation } \\
\text { Gap }\end{array}$} & The & Every auditor with any educational background can carry out a performance audit. \\
\hline & competence \& & However, the majority of auditors have an educational background in economics, which \\
\hline & $\begin{array}{l}\text { Qualifications } \\
\text { of Auditors }\end{array}$ & makes their mindset still in a financial / compliance audit. \\
\hline & Independence & $\begin{array}{l}\text { Auditors develop a semi-consultative role, where they informally provide operational } \\
\text { advice and help the auditee to improve performance. This has the potential to disrupt } \\
\text { the independence that makes the auditor difficult to be objective }\end{array}$ \\
\hline & $\begin{array}{l}\text { Benefits of } \\
\text { Performance } \\
\text { Audit }\end{array}$ & $\begin{array}{l}\text { The performance audit is felt to be beneficial, but not much. However, the auditee still } \\
\text { considers performance audits to be important, namely the legitimacy of independent } \\
\text { parties as a form of their accountability to the public. }\end{array}$ \\
\hline $\begin{array}{l}\text { Oliver } \\
\text { Strategic } \\
\text { Response }\end{array}$ & $\begin{array}{l}\text { Five typologies } \\
\text { of response: } \\
\text { agree, } \\
\text { compromise, } \\
\text { avoid, } \\
\text { challenge \& } \\
\text { manipulation }\end{array}$ & $\begin{array}{l}\text { Auditee provides different responses to the influence of the auditor as well as findings } \\
\text { and recommendations for performance audits. Various auditee tactics and strategies } \\
\text { were carried out by the auditee in response to auditor determination and action. } \\
\text { Each response depends on how well the relationship and communication with the } \\
\text { auditor, as well as their motivation, interests and intentions based on the results of the } \\
\text { performance audit. }\end{array}$ \\
\hline
\end{tabular}

Source: Adapted from Katz \& Kahn (1978) and Oliver, C. (1991)

order to improve the performance of a policy or organization. In auditor perceptions, they are aware of this role and emphasize that the auditor's agency is to provide awareness and new knowledge to the auditee. The awareness and the knowledge are on problematic matters. In addition, it determines the cause and provides recommendations so that the cause is completed and will not be repeated in the future. The auditor also refuses to play an active role in making decisions that change the policy because this will disrupt their independence.
On the other hand, the auditee considers that auditors should assist them in conducting direct supervision or supervision in policy implementation. It will later affect immediate resolving. In addition, the auditee expects that the recommendations given are technical and solutive, not just suggestions in general that takes time for them to formulate actions from these recommendations.

By using the concept of role taking, researcher can analyze the three social factors that surround auditor relations and the auditee 
including personal, interpersonal and external factors. In personal factors, researchers can find that the auditor's educational background and the determination of methods in performance auditing are determining factors in the relations of auditors and auditees. The absence of an educational institution or special certification regarding performance audits has contributed to the conflicts that arise between auditors and auditees in the performance audit process. In interpersonal factors, it was found that there were potential problems in auditor independence, which resulted in a continuous search for the ideal concept of independence. The task of auditors is to assess aspects of $3 \mathrm{E}$ and provide recommendations. Moreover, the task to get pressure from the auditee continuously causes compromise on their independence. In addition, the concept of independence at the operational level was also felt to be inadequate so that they were confused when deciding on an action whether or not to interfere with independence. In external factors, it is found that there is ambiguity over the value added concept in the performance audit.

Ambiguity is a value inherent in performance audits caused by many things such as multi-purpose policies, too quantified performance, and the absence of special institutions. Furthermore, using the concept of gap audit expectations the researcher can analyze how auditors and auditee perceive three important concepts, namely auditor qualifications, independence, and the benefits of a performance audit. Based on field data, this study reveals that there is no single educational background or special qualifications for auditors in carrying out performance audits. However, the majority of auditors with educational qualifications in economics or accounting encourage the use of the mindset of financial audits or compliance when they are conducting audits. This has made it difficult for auditors to understand business processes and develop better audit criteria. The next important concept is related to independence, where auditors develop a semi-consultative role that results in their independence being compromised and it is difficult to be objective. Other concepts related to the benefits of performance audits are felt in real terms. However, the auditee still considers performance audits to be important, namely the legitimacy of independent parties as a form of their accountability to the public.

Finally, by using the concept of strategic response, researchers can identify how the response and resistance shown by the auditee when they deal with the behavior and actions of the auditor in influencing them. In this case, the auditee has different tactics and strategies both when they agree or disagree with the auditor and the results of the performance audit. Each response has behavioral characteristics. The auditee uses them so that the value that the auditor tries to provide is in accordance with the will and motivation. In the circumstances that the value is in accordance with the motivation, the auditee will respond according to the value given. However, when the value offered is different, they will try to compromise so that the value can be modified according to what they want. Another case when the value can shake the position, the auditee tends to be able to respond actively through avoiding, challenging and even manipulating tactics according to their motivation.

\section{Conclusions}

The findings of this study indicate that there are differences in perceptions between auditors and auditees, especially regarding benefits or added value in performance audits that are considered insignificant. The auditor considers that his job is only to provide limited recommendations as his responsibility. The auditee will be more appreciative if the auditor can provide technical recommendations and play a direct role in public policy making. Even though the impact audit performance was not too pronounced, the auditee still considered the 
performance audit important. This is because they still need an assessment or perspective from an independent third party as a form of accountability and transparency of policy to the public.

Some suggestions or policies that can be done to improve performance audit practices are as follows. First, the Republic of Indonesia's BPK needs to specialize in auditors who carry out performance audits. Specialization is done to change the auditor's paradigm of thinking, so that it does not use the same mindset between performance audits and financial audits. The scope of public policy covers a very broad field, which involves many professions and specialization expertise. The existence of this very wide scope causes no standards or criteria that apply to all. Each entity or object of audit is unique and has a different business process. In this case, auditors who have the mindset of special performance audits are expected to conduct audits more flexibly, dare to develop audit criteria and provide conclusions and recommendations in accordance with their professional judgment. In addition, changes in mindset also make auditors brave enough to try various audit methods so that the performance audit process can be more in-depth. Secondly, the Republic of Indonesia BPK must socialize and internalize the performance audit to the entity being examined. Based on the findings in the field, it can be seen that there is a performance audit that is still only seen as a tool for the legitimacy of the auditee from independent parties. It is within the framework of accountability to the public. In addition, there are differences in deep perceptions of the role of the auditor, especially the expectations of the auditee. It will affect that auditors can play an active role and help them directly in improving performance. In this case, the BPK RI can provide further clarification on the concept of performance audit and its scope to the auditee. Thus, the insight and knowledge of the auditee about the concept of performance audit can increase, while differences in perceptions of the role of the auditor can be minimized. Third, the BPK RI must continue to improve professional expertise and training of auditors who carry out performance audits. Increasing this competency must be supported by the right curriculum so that the practice of audit performance will be better in the future. In addition, this training program must be evaluated regularly so that it is in accordance with the policy developments in the community.

Recruitment of auditors with educational backgrounds from social sciences can also help BPK RI to see policies from a broader perspective. It would be better if the Republic of Indonesia's BPK could form a special unit that conducts auditor assessment and certification with the ability to carry out performance audits. Fourth, the Republic of Indonesia's BPK must re-conceptualize the meaning of independence and practice in the field. Lack of clarity and lack of guidance on how to practice ideal independence, can prevent auditors from innovating or taking steps to be taken. In the field, auditors faced many obstacles that required them to think whether this would interfere with their independence or not. This makes them hesitant in making decisions that might really bring improvements to the auditee. Fifth, the Republic of Indonesia BPK together with the government seeks to develop qualitative performance indicators. The lack of appropriate and substantive performance indicators is a crucial problem that must be overcome. The involvement of both parties can be reached regarding this qualitative indicator. In addition, the development of this indicator can also be assisted by other parties such as universities or experts in their respective fields. Sixth, the Republic of Indonesia BPK together with the government developed guidelines for the best management practices concept. The lack of understanding of best management practices and the absence of guidelines in this concept, made it difficult for the auditee 
to find the right reference to improve their performance.

This study has limitations. Participants were selected based on sampling so that there may be differences in perceptions between auditors and auditees that cannot be found elsewhere. This shows that the results of this study are only suitable for participants interviewed, and is not suitable for other entities. Thus, future research can about other participants in other places or including broader objects. For example, future research is carried out on a performance audit that has been carried out for a long period, which result on different perception. The next limitation is in case of in auditor's role who has changed from a supervisory role to another four roles. In the future, the possibility of changes in the public policy paradigm can change, and this affects changes in the auditor's role in the future. Thus, future research can be focused on changing roles that occur according to changes in the context of policy. This study includes many problems, one of which is discussing three factors at once in the social process. The existence of this broad scope, can cause this research may not be too deep in discussing one of these factors. Thus, future research can overcome one aspect of three factors. For example, research on interpersonal factors between auditors and auditees related to independence and practice in the field can be done. Alternatively, research on the influence of auditors' and auditee's educational background in performance audits will be possible.

\section{References}

Alasuutari, P. (2010). The rise and relevance of qualitative research. International journal of social research methodology, 13(2), 139-155.

Cassel, C., \& Symon. (1994). Qualitative methods in organizational research. California: Sage.

Davis, D. F. (1990). Do you want a performance audit or a program evaluation? Public Administration Review, 50(1), 35.
Gendron, Y., Cooper, D. J., \& Townley, B. (2001). In the name of accountability-State auditing, independence and new public management. Accounting, Auditing $\mathcal{E}$ Accountability Journal, 14(3), 278-310.

Heimer, K., \& Matsueda, R. L. (1994). Roletaking, role commitment, and delinquency: A theory of differential social control. American Sociological Review, 365-390.

Humphrey, C., Moizer, P., \& Turley, S. (1993). The audit expectations gap in Britain: An empirical investigation. Accounting and Business Research, 23(sup1), 395-411.

Katz, D., \& Kahn, R. L. (1978). The social psychology of organizations (Vol. 2): Wiley New York.

Lapsley, I., \& Pong, C. (2000). Modernization versus problematization: value-for-money audit in public services. European Accounting Review, 9(4), 541-567.

Leeuw, F. L. (1996). Performance auditing, new public management and performance improvement: questions and answers. Accounting, Auditing \& Accountability Journal, 9(2), 92-102.

Lindeberg, T. (2007). The ambiguous identity of auditing. Financial Accountability $\mathcal{E}$ Management, 23(3), 337-350.

Morin, D. (2014). Auditors General's impact on administrations: a pan-Canadian study (2001-2011). Managerial Auditing Journal, 29(5), 395-426.

Oliver, C. (1991). Strategic Responses to institutional processes. The Academy of Management Review, 16(1), 145-179.

Parker, L. D. (1986). Value-for-money auditing: conceptual, development and operational issues. Australian Accounting Research Foundation.

Pollitt, C., \& Summa, H. (1997). Reflexive watchdogs? How supreme audit institutions account for themselves. Public administration, 75(Summer), 313-336.

Power, M. (2000). The Audit Society-The Second Thoughts. International Journal of Auditing, 4, 111-119. 
Raudla, R., Taro, K., Agu, C., \& Douglas, J. W. (2016). The impact of performance audit on public sector organizations: The case of Estonia. Public Organization Review, 16(2), 217-233.

Reichborn-Kjennerud, K. (2015). Resistance to control-Norwegian ministries' and agencies' reactions to performance audit. Public Organization Review, 15(1), 17-32.

Sikka, P., \& Willmott, H. (1995). The power of "independence": defending and extending the jurisdiction of accounting in the United
Kingdom. Accounting, organizations and society, 20(6), 547-581.

Stewart, J., \& Walsh, K. (1994). Performance measurement: when performance can never be finally defined. Public Money $\mathcal{E}$ Management, 14(2), 45-49.

Vikkelsø, S. (2007). In between curing and counting: performative effects of experiments with healthcare information infrastructure. Financial Accountability $\mathcal{E}$ Management, 23(3), 269-288. 